\title{
DYNAMICS OF VIRAL ADVERTISING
}

\author{
Ayşe Binay KURULTAY \\ Yeditepe University, Faculty of Communications, Istanbul \\ abinay@yeditepe.edu.tr
}

\begin{abstract}
Digital technologies have heightened the debate on convergence where technologies, corporations and people [target audiences] meet. New media has become a new meeting place and a social platform for people. As more brands choose to employ relationship marketing strategies that emphasize consumer's experience with the brand, it is inevitable that they explore opportunities to connect with their target audiences in this new meeting place. Thus, user-created content and electronic word of mouth [eWOM] have become important concepts for influential and noteworthy advertising campaigns in this new medium. The aim of this study is to understand the dynamics of viral marketing campaigns and to identify the strategies that make viral advertising successful. International cases, such as brand applications of 3D Mapping Projections are used to understand the relationship between cutting-edge digital art and their use in advertisements. Recent Turkish viral ad campaigns such as Profilo's "O Tabak Bitecek!" [Finish everything on your plate] and Turkish Airlines Miles and Smiles' "İnanılmaz Evlenme Teklifi" [Unbelievable Proposal] disseminated through social networks are used as cases to identify the message strategies used in making these advertisements successful.
\end{abstract}

Keywords: Advertising, Viral Advertising, 3D mapping projection, Branding

\section{INTRODUCTION}

The terms viral marketing, viral communication, buzz marketing, word-of-mouth marketing, electronic word-of-mouth advertising (eWOM) and viral advertising are all terms that center around a concept that differs from traditional advertising [1]. Viral communications utilize the pre-existing social connections in order to spread the desired message. Viral marketing is based on the idea that consumer discussions about a product or a brand are more valuable and powerful than traditional advertising. For viral advertising to be successful, there must be a core viral element in the content of the communication. It is also important for the target audience to be equipped with the tools that are necessary to disseminate the content. As listed above, there is a range of terms used for viral communication in academic literature. The theories and beliefs are varied, yet at the core, these seemingly different concepts focus on similar phenomena. Thus, it seems to be wise to define viral advertising using necessary elements of these varied descriptions, yet clearly differentiate it from traditional advertising.

\subsection{Viral Advertising}

Viral marketing was first introduced by media critic Douglas Rushkoff in his book Media Virus in 1994. It was further theorized by Jeffrey Rayport in an article in Fast Company magazine. Viral marketing model is explained with the analogy of an infectious disease. As consumers let each other know about the content, the communication message is spread similar to a virus, with human contact. Six fundamental principles were explained in order for viral marketing to succeed. Using stealth and subtlety to convey the message, giving free stuff up-front, exploiting peer-to-peer networks in order to spread the message, making the message memorable and 'sticky', exploiting the strength of weak ties and working to reach a tipping point were the initial principles that viral marketing is based on. [2] In 1997, Steve Jurvetson brought the concept to public attention with a Netscape newsletter [3].

As Seth Godin explains, "the idea is to create an environment where consumers will market to each other" instead of trying to market at them. An ideavirus is a "fashionable idea that 
propagates through a section of the population, teaching and changing and influencing everyone it touches." As consumers are not obsessed with products but with ideas, it is imperative that the viral strategy is based on an inherently brilliant idea in order to reach its target audience. "Viral marketing is an ideavirus, but not all ideaviruses are viral marketing. Viral marketing is an ideavirus in which the medium of the virus IS the product." [4]

Rosen's concept of "buzz" that is defined as "the sum of all comments about a certain product that are exchanged among people at any given time" is similar to the "ideavirus." Rosen argues that people share a message about something that relates to their lives therefore the challenge for viral marketing is to stimulate this pass-along process artificially. [4] Gladwell shows that ideas, products and even behavior patterns can spread just as viruses do. Contagiousness and epidemics are the central ideas that explain the dynamics of viral phenomena. [8] Contagiousness is also related with the idea of "memes." A meme is explained as a "unit of cultural transmission, or a unit of imitation. ...Examples of memes are tune, ideas, catch-phrases, clothes, fashion, ways of making pots or building arches. ...memes propagate themselves in the meme pool by leaping from brain to brain via a process which, in the broad sense, can be called imitation." [6] Since consumers' minds are cluttered from information overload, the success of the message relies on its infectiousness. Creativity and uniqueness of the message clearly create the basis of a potent meme. Viral advertising differs from viral marketing in the sense that the former refers to a comprehensive marketing strategy while viral advertising is the online advertising technique. Thus it is important to investigate the similarities and differences between traditional and viral advertising.

Advertising is traditionally defined as "paid persuasive communication that uses non-personal mass media to reach broad audiences to connect an identified sponsor with a target audience" [7]. When advertising becomes viral, it changes some of its traditional properties. While traditional advertising is non-personal, viral advertising is highly personal. The content of viral advertising is intended to be shared among trusted sources such as friends and family. In other words, viral advertising aims for personal recommendations. The sponsors in viral advertising, although usually not as overt as traditional advertising, can be identified. Through the provocative content of the sponsor, viral advertising's aim is to associate positive feelings to the product or brand. Provocative content may be achieved by the use of humor as well as emotional appeals so that the consumer is inclined to pass it along to other users. Viral advertising might use elements of mass communication, however its main medium is the Internet. Thus, viral advertising can be defined as "unpaid peer-to-peer communication of provocative content originating from an identified sponsor using the Internet to persuade or influence an audience to pass along the content to others." [1]

Focusing on eWOM, early studies that focused on forwarding email concluded that advertisers mainly concentrate on "desires for fun, entertainment and social connections" [9]. Most viral advertising follows this recommendation. Although an inspiring tool, viral marketing is open to overuse as a concept to push products that are not inherently viral. Some marketers are inclined to use a new concept ad nauseam boring the public with the same tools of reaching the consumers. Yet, consumers are able to use their judgment on forwarding content [5].

\section{STRATEGIES FOR SUCCESSFUL VIRAL ADVERTISING}

\subsection{Raw, provocative content}

Viral advertising depends heavily on provocative content to "motivate unpaid peer-to-peer communication of persuasive messages from identified sponsors" more than traditional advertising. Although emotional content has been the key influencer in captivating traditional advertising audiences, with viral advertising, raw content tends to be a more important element for actual dissemination. [1] Viral advertising works better when the content is surprising, unique, challenging or inspiring. 


\subsection{Use of humor}

Humor and sexuality are the main advertising appeals used in viral advertisements $[1,9]$. Humor is found to be one of the two main memes that make the advertisements worth forwarding to others. However, fashion industry and issue advocacy viral advertisements use humor significantly less than other industries [1].

\subsection{Use of emotional appeal}

Viral advertising aims to associate a momentary good feeling experiences from the raw content, which is provocative enough to make an impact on the consumer with the sponsor [1]. Using emotions to create this bond between the advertiser and the viral content is a classic advertising idea that has been used successfully in traditional advertising as well.

\section{2 "Stickiness"}

The viral concept can be explained as epidemics are explained. The messenger matters in epidemics since $\mathrm{s} / \mathrm{he}$ plays an important role in spreading the epidemic. As the person who spreads the viral concept is important, the actual content of the message is as important. The "stickiness" of the content is what defines the viral concept as worthy of passing along to others. Memorability can be identified as the core for "stickiness" as it acts as the most important decision criteria for spurring someone to action. [8]

\subsection{Product as part of the communication process}

When the product itself has passive viral features, studies show that peer-to-peer promotion increases compared to products without viral features. [11] It is then important for products to become part of the viral content.

\section{3D MAPPING PROJECTION}

3D projection mapping is a form of graphics or video content projected on the surface of a building or object [12]. Powerful electric arc lights were illuminating public monuments in Paris, which date the history of projections back to 1840s. In the United States, in the 1860s, a "stereopticon" was used to project slides outdoors on screens, walls and public monuments. In 1866, projections were used to announce election results [13]. Today, projections are used for entertainment and art purposes. Furthermore, commercial use of entertainment tools is expected. Projection mapping was co-opted starting from 2009 and this spectacular light show has been used by many brands. 3D projections can be considered as a form of spectacle that creates its own buzz. This quality puts $3 \mathrm{D}$ projections in a prime spot for viral advertising content.

The projection mappings are treated as a regular animation project and a "graphical score, a waveform that sets the emotional tone of the piece" is created. An "abstract narrative" is formed and the audience then reconstructs the narrative as a part of the show. As a result it becomes a narrative the audience interacts with instead of just a light show [12]. Following are some of the $3 \mathrm{D}$ projection mapping examples that have created an impact on the audiences and have been viewed on social media by thousands.

\subsection{Samsung 3D TV Amsterdam}

Between May 20 and May 22 2010, Samsung implemented a 3D projection on the façade of the Beurs van Berlage in Amsterdam. The use of the architectural details of the building resulted in extraordinarily lifelike effects in this application of 3D projection mapping. The product affiliated with this event, a 3D TV, highly benefits from the well-executed digitalization of visuals. The Samsung case is a great example of the impact of raw content. 


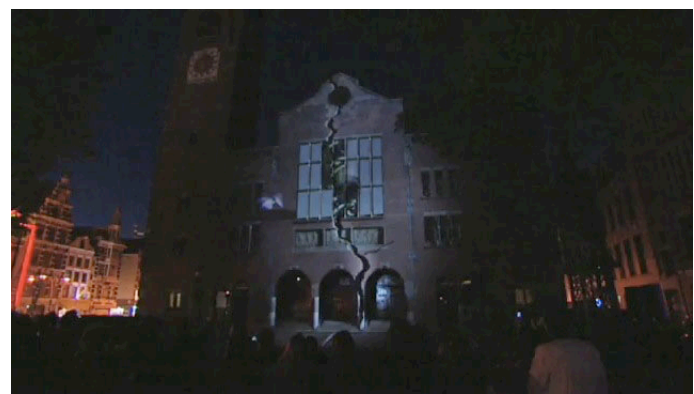

Figure 1. Samsung 3D TV projection mapping on Beurs van Berlage

\subsection{Bombay Sapphire Re-Powered - London, UK}

The Re-powered campaign was created with the collaboration of RKCR/Y\&R and Drive Productions in 2010 and was displayed on Battlesea Power Station on June 8 (Figure \#). It is the continuation of a previous $3 \mathrm{D}$ projection campaign that featured sea creatures in a blue ocean projected onto Queen's House in Greenwich in September 2009. After the first projection, fans on Facebook suggested ideas for the Battlesea Power Station projection and the winning idea was a giant Rubik's cube that became the theme for the Re-powered campaign [14]. This projection is an example of the use of an iconic landmark building in 3D projection events.

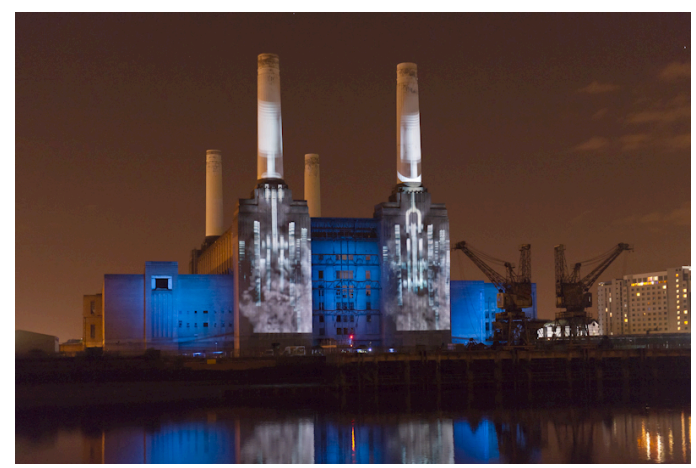

Figure 2. Bombay Sapphire projection mapping on Battlesea Power Station

\subsection{Saks Fifth Avenue New York}

On November 22 2010, Saks Fifth Avenue unveiled their iconic holiday window display in New York. Their window display for the holidays is enjoyed by New Yorkers as well as tourists every year during the holidays. The $3 \mathrm{D}$ projection mapping along with original music ran every night for 6 weeks in December 2010. This event was the first in terms of scale and duration. The story of the snowflake, which is their signature design, and bubble create a warm feeling and holiday associations that relate to the spirit of the season developing the brand story for Saks Fifth Avenue.

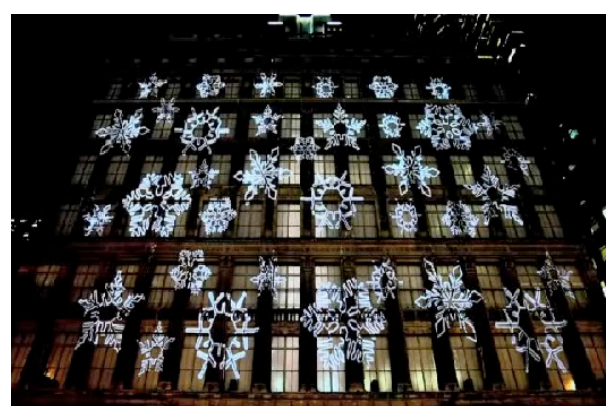

Figure 3. Saks Fifth Avenue 3D projection 


\subsection{Wrigley's 5 Gum South Africa}

Wrigley showcased the first user-generated 3D projection events in Johannesburg on May 17182011 and Cape Town on May 20-21 2011, South Africa. [15] In the campaign created by TribalDDB South Africa, users first created their own personalized 3D building projections online (http://www.5gum.co.za) and submitted their work through a website [Figure 4]. The best participants were rewarded with watching their projections live onto landmark buildings [16].

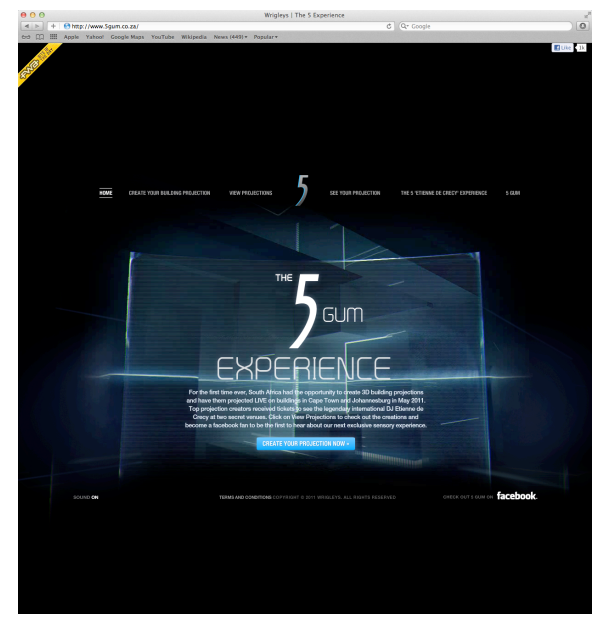

Figure 4. Wrigley's 5 gum 3D building projection website

As explained earlier, it is important for viral advertising to include the product as a communication tool. In the Wrigley case, the projection becomes the interactive viral advertising created by the consumers.

\subsection{Adidas France}

One of the most impressive 3D projection mapping campaigns in 2011 was the Adidas France's "Adidas is all in" campaign event on March 232011 at the Palais du Pharo in Merseille, France. The scale of the project as well as the creative direction build the intensity of Adidas brand identity. It is important that the brand identity, story and associations are in complete unison with the tone of the narrative of the projection. The Adidas France case might be shown as one of the best examples for "stickiness" of the content. In the end, it is the story that sticks.

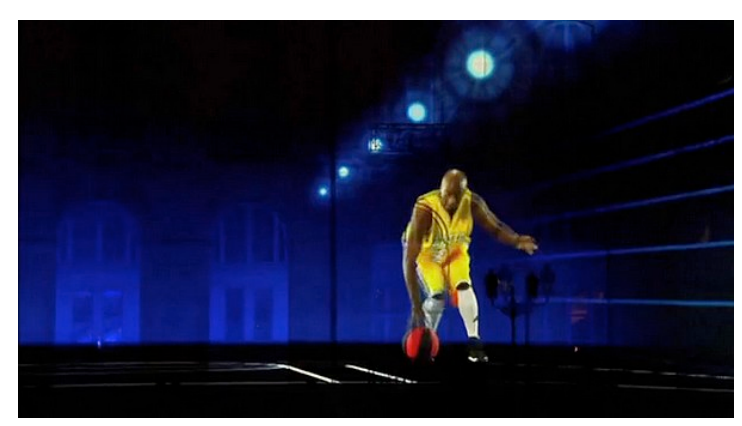

Figure 5. Adidas France 3D building projection at Palais du Pharo

\subsection{Profilo "O Tabak Bitecek!" [Finish everything on your plate]}

Profilo, a Turkish white goods brand, launched a viral advertising campaign for Mother's Day 2011 with the "the things Turkish moms say" concept. The viral advertisement created by Trafo is based on an original song with the lyrics repeating various "mom saying" such as "finish everything on your plate". As mentioned earlier, humor plays a key role in viral advertisements and this campaign is a textbook example of successful usage of humor in viral advertising. 


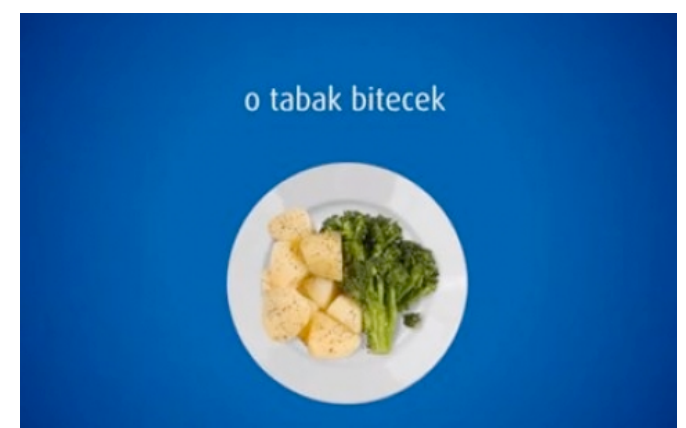

Figure 6. Profilo viral advertising campaign

\subsection{Turkish Airlines Miles and Smiles "İnanılmaz Evlenme Teklifi" [Unbelievable Proposal]}

Turkish Airlines reward program Miles and Smiles launched a viral advertising campaign on April 182011 and the video was watched more than 50,000 times in less than 24 hours. The story behind the viral advertisement made by Fakülte was about a young man traveling to 14 countries with his free miles and videotaping locals say phrases in Turkish in order to make a montage of the footage with a specific message to his girlfriend, asking her to marry him. This viral advertisement was part of a viral marketing campaign with a proper website to go along with the ad. In the website (ididitallforyou.tumblr.com), the "making-of" the proposal video is documented. With every country visited, there is a new entry to the blog.

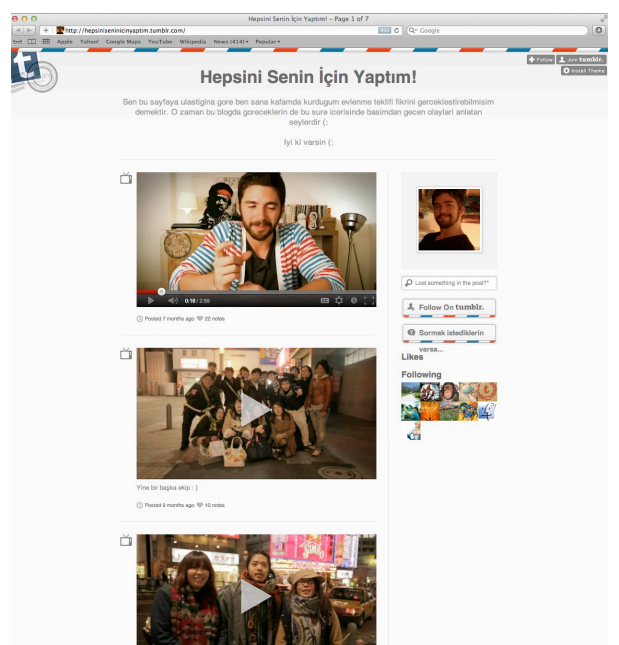

Figure 7. Unbelievable Proposal campaign blog

This is a successful example of all the elements mentioned earlier, raw content, emotional appeal, use of humor, "stickiness" and the use of the product in the content of the viral itself.

\section{REFERENCES}

[1] Porter, L., Golan, G.J. (2006). 'From Subservient Chicken to Brawny Men: A Comparison of Viral Advertising to Television Advertising'. Journal of Interactive Advertising 6(2): 2633.

[2] Rayport, J. (1996). 'The Virus of Marketing' Fast Company 6(December). Available at http://www.fastcompany.com/magazine/06/virus.html [20 December 2011]

[3 ] Jurvetson, S., Draper, T. (1997). 'Viral Marketing'. Available at http://www.dfj.com/news/article_26.shtml [22 December 2011]

[4] Godin, S. (2001). Unleashing the Ideavirus. New York: Do You Zoom.

[5] Rosen, E. (2000). The Anatomy of Buzz. New York: Random House.

[6] Dawkins, R. (1976). The Selfish Gene. New York: Oxford University Press. 
[7] Wells, W, Moriarty, S., Burnett, J. (2006). Advertising Principles and Practice. New Jersey: Pearson Prentice Hall.

[8] Gladwell, M. (2002). The Tipping Point. New York: Time Warner.

[9] Phelps, J. E., Lewis, R., Mobilio, L., Perry, D., Raman, N. (2004). 'Viral Marketing or Electronic Word-of-Mouth Advertising: Examining Consumer Responses and Motivations to Pass Along Email'. Journal of Advertising Research 44(December): 333-348.

[10] Golan, G.J., Zaidner, L. (2008). 'Creative Strategies in Viral Advertising: An Application of Taylor's Six-Segment Message Strategy Wheel'. Journal of ComputerMediated Communication 13: 959-972.

[11] Aral, S., Walker, D. (2011). 'Forget Viral Marketing - Make the Product Itself Viral'. Harvard Business Review June: 34-35.

[12] Snoad, L. (2011). '3D Projection Mapping: Brand Theatrics'. Design Week 26 May 2011: 15 .

[13] Krautsack, D. (2011). '3D Projection Mapping and its Impact on Media \& Architecture in Contemporary and Future Urban Spaces'. Media-N: Journal of the New Media Caucus 7(1). Available at http://www.newmediacaucus.org/wp/media-n-journal [12 December 2011] [14] Bombay Sapphire Re-powered (2011). 'Bombay Sapphire Re-powered'. Campaign (UK) 24: 8 .

[15] http://tribalddb.withtank.com/2011/05/07/wrigleys-5-gum-launch-campaign-live [2 December 2011]

[16] http://creativity-online.com/work/wrigleys-5-gum-3d-building-projection/23214 [2 December 2011] 